\title{
A klippe of Nagssugtoqidian supracrustal rocks at Sarfartûp nunâ, central West Greenland
}

\author{
C. J. Talbot
}

\begin{abstract}
Supracrustal rocks comprising subaqueous volcanics, basic and ultrabasic sills and clastic carbonate sediments are unconformable upon quartzo-feldspathic gneisses and together form a small klippe of imbricate thrust slices. The sills were intruded after the other rocks had been folded and metamorphosed at low amphibolite facies. The whole allochthon suffered penetrative strain in hydrous conditions as it translated southwards as two discordant sets of imbricate thrust nappes. All the thrusts are folded about axial planes which were originally recumbent. As the higher slices arrived, the deeper slices refolded about axial planes dipping about $60^{\circ} \mathrm{NNW}$. All these early folds are close to co-axial with a strong mineral orientation in a syn-translation foliation.

It is suggested that the sills are shallow correlatives of the Kangâmiut dykes and that the allochthon was transported $60 \mathrm{~km}$ from a Nag. 2 zone of strong ductile overthrusting near Ikertôq. The tectonic relationships of these Proterozoic supracrustals are intermediate between those in Phanerozoic ophiolites and Archaean greenstone belts.
\end{abstract}

\section{Introduction}

A group of allochthonous thrust slices of supracrustal rocks is exposed in a small (10-15 $\left.\mathrm{km}^{2}\right)$ cluster of low hills $(\sim 400 \mathrm{~m})$ high on the plateau $(>1000 \mathrm{~m})$ in central West Greenland at Sarfartûp nunâ $\left(66^{\circ} 27^{\prime} \mathrm{N}, 52^{\circ} 00^{\prime} \mathrm{W}\right)$. This isolated klippe is, geographically, about five kilometres north of the Sukkertoppen ice cap and a similar distance easi of Søndre Strømfjord (fig. 1). Geologically it is preserved as an E-W elongate basin infolded into the autochthon 15-20 km NW and $\mathrm{N}$ of the irregular ductile overthrust southern margin of the Proterozoic Nagssugtoqidian mobile belt (Escher et al., 1975). The rocks at Sarfartûp nunâ provide a useful and rare, if not unique, record of what happened at comparatively shallow crustal levels during the Nagssugtoqidian remobilisation of the Archaean crust in spaced zones of ductile shear.

This description of the geology of Sarfartûp nunâ is based on observations made together with John Diggens of Kingston Polytechnic during a ten day period in August 1973. I am very grateful to John Diggens for the long discussions we had in the field and while the credit for many of the observations and interpretations belong to him any mistakes incorporated here are definitely my own. 


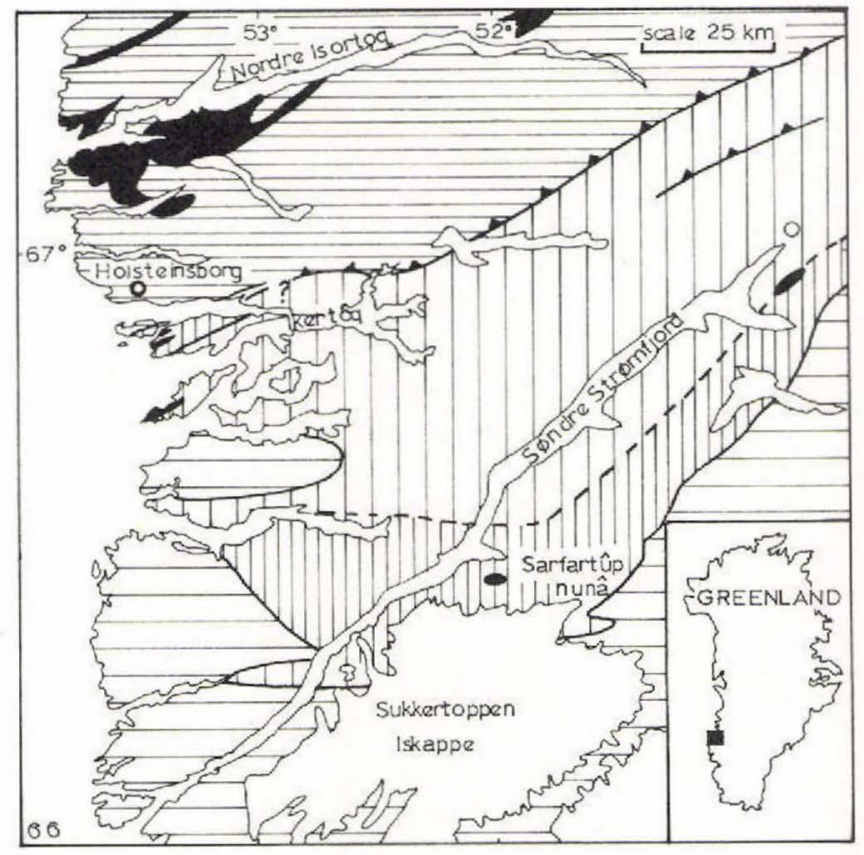

Fig. 1. Map showing location of known supracrustals (black), Archaean granulite facies (open horizontal ruling), Nagssugtoqidian granulites (close horizontal ruling), and Nagssugtoqidian amphibolite facies (vertical ruling) in part of central West Greenland. Zones of Nag. 2 overthrust shearing are shown by more closely spaced vertical ruling than the zones of Nag. 1 transcurrent shear.

\section{Lithologies}

The allochthonous supracrustal rocks at Sarfartûp nunâ have all been metamorphosed at either lower amphibolite or greenschist facies. They consist of four components: (1) subaqueous volcanics associated with early basic and ultrabasic high level intrusives and (2) sediments which together accumulated unconformably on (3) quartzo-feldspathic gneisses. This succession may have suffered an early deformation and metamorphism before being intruded by (4) a later suite of basic sills. They were then detached from the area in which they accumulated and moved south or south-eastwards to their present location. Some minor kimberlite dykes are the only rocks emplaced after the allochthon arrived at its present location.

\section{(1) Metavolcanics}

Most of the supracrustals consist of more or less deformed volcanics associated with hypabyssal intrusions some of which locally approach ultrabasic (pyroxenite) compositions. Actinolite schists are most characteristic of the metavolcanics. A specimen of one of the least deformed of these consists largely of zoned actinolite orientated to define a crude foliation which does not obscure an original porphyritic texture with a fine grained groundmass darkened by opaque minerals. In the field, many such actinolite schists are obviously deformed pillow lavas. In several of the thrust slices piles of pillows (e.g. $100 \times 50 \mathrm{~m})$ are intimately associated with garnetiferous amphibole-feldspar dykes and sills which appear to 
have both supplied and intruded the pillows. Some of these intrusive bodies are hydrated but essentially undeformed and include volumes of ultrabasic composition (e.g. medium grained pyroxenites partially replaced by large blades of tremolite $-7 \times 0.5 \mathrm{~cm}$ ).

Traced laterally the pillows commonly assume an amygdaloidal nature before giving way to deformed but obvious pillow breccias. When traced still further along the strike the clasts in such agglomerates decrease in size and become less obviously derived from rounded pillows with chilled margins. Exposure is sufficiently good in many parts of the upper two thrust slices that transitions from pillow lavas through pillow breccias to actinolite albite \pm chlorite, muscovite schists with minor quantities of opaque minerals are preserved (fig. 2). Such fine grained actinolite bearing schists are thought to represent metamorphosed tuffs and some were identified as crystal tuffs in the field and most probably originated as hyaloclastic tuffs. Particular horizons of actinolite schists extend along strike for over a kilometre but throughout the generally similar supracrustal succession preserved in each thrust slice they display transitions both laterally and vertically to fine grained clastic metasediments. These are represented by siliceous muscovite ( \pm chlorite) phyllites through areas in which layers of chlorite + albite + opaque minerals interfinger with muscovite-albite phyllites on scales from centimetres to tens of metres. In other areas various proportions of (presumably clastic) $0.2 \mathrm{~mm}$ diameter quartz grains contaminate garnetiferous actinolite-albite (tuffaceous) schists.

\section{(2) Metasediments}

Laterally persistent beds up to $30 \mathrm{~m}$ thick of muscovite-rich quartzites with annealed textures were originally deposited directly onto the basement gneiss. Now, however, they are incorporated within a metabasic sill intruded along this unconformity. Various quantities of additional feldspar, biotite and garnet in this and other impersistent clastic sedimentary horizons throughout the supracrustal pile represent transitions to psammites (fig. 2). Two patches of garnetiferous schists containing quartz, biotite, chlorite, feldspar and opaque minerals together with late porphyroblasts of kyanite are interpreted as lenses of pelites.

Anthophyllite schists up to approximately $30 \mathrm{~m}$ thick are common throughout the supracrustal succession. These usually contain anthophyllite, albite \pm muscovite \pm chlorite and dolomitic calcite but locally the calcite assumes significant proportions. Most of the anthophyllite in what are assumed to have been impure carbonate sediments forms spectacular post-kinematic rosettes often about $1 \mathrm{~cm}$ in diameter (garbenschiefer).

\section{(3) Basement gneisses}

Thrust slices numbered 3 and 6 to 9 on figures 3 and 4 incorporate various thicknesses $(<250 \mathrm{~m})$ of leucocratic and mesocratic gneisses on which the metasediments and metavolcanics can locally be seen to have accumulated unconformably before the thrusting developed. Rare mesocratic gneisses of feldspar, biotite and hornblende ( \pm quartz) display diffuse transitional boundareies with the more common quartz-rich feldspathic gneisses. In thrust slices 7 and 8 basic metavolcanics which accumulated directly on leucocratic gneisses were undisturbed by the later basic sill injected along the unconformity elsewhere. Where it is undisturbed the unconformity has some relief (of perhaps $30 \mathrm{~m}$ over a strike of $100 \mathrm{~m}$ ) and 


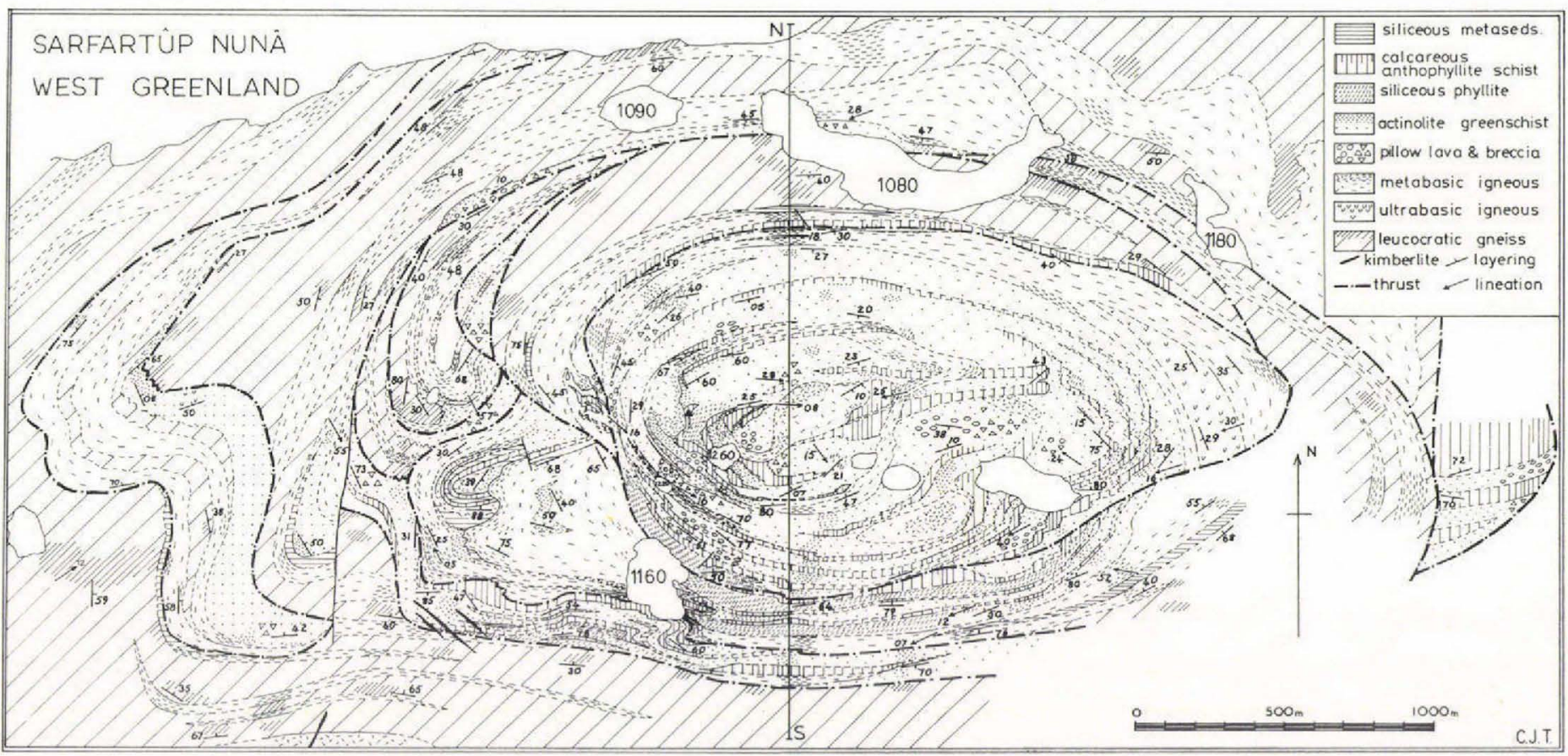

Fig. 2. A geological sketch map of Sarfartûp nunâ. The scale is only approximate. Each lithology is shown by two symbols, the more closely spaced of which indicates exposure visited while mapping. See figure 1 for location. 


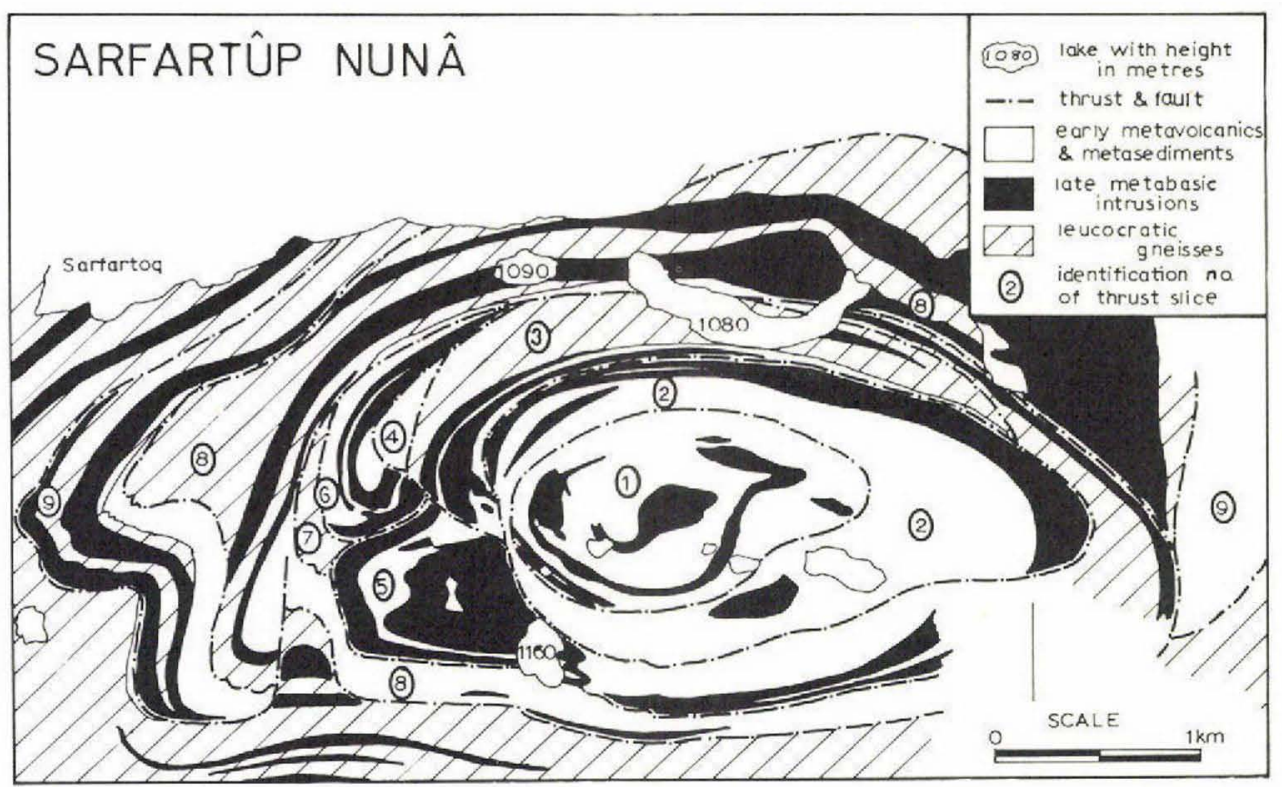

Fig. 3. The major lithological and structural units of Sarfartûp nunâ. The thrust slices are numbered downwards for descriptive purposes.

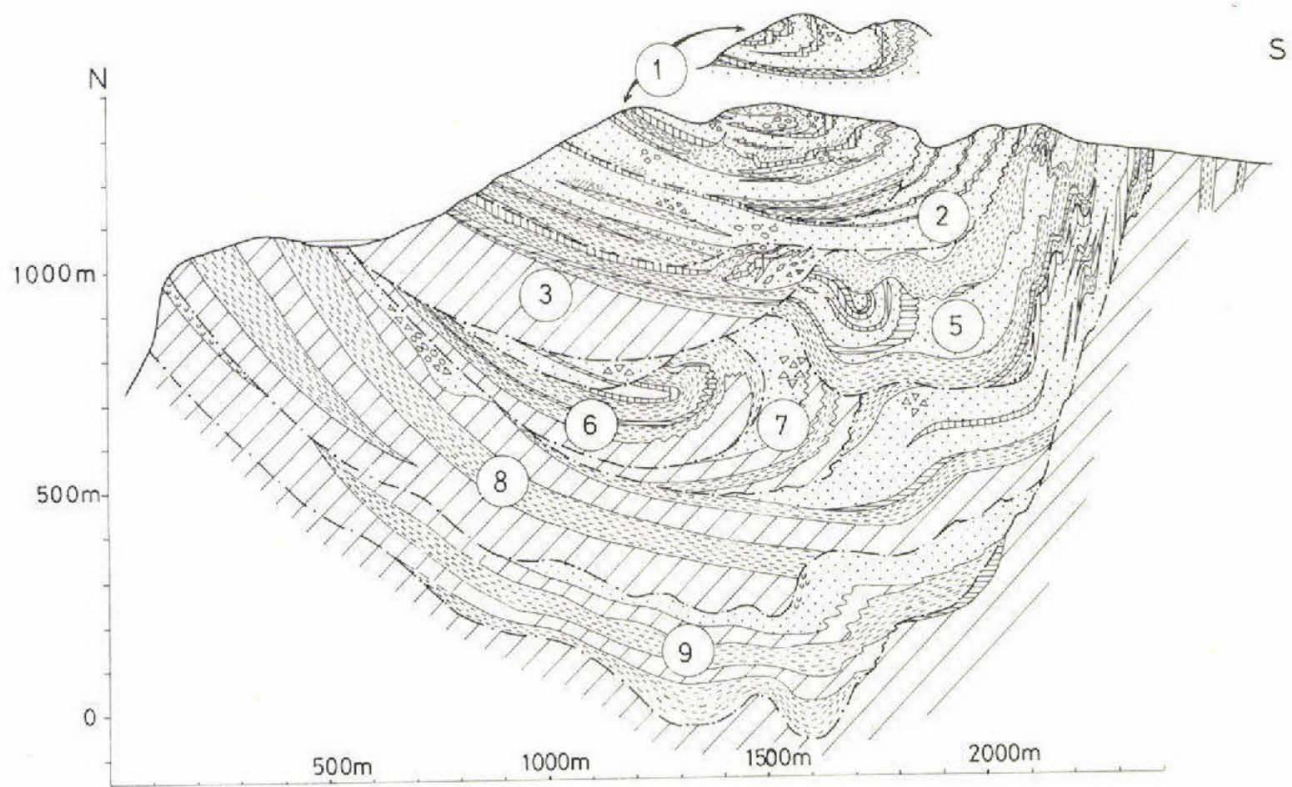

Fig. 4. A N-S cross-section through Sarfartûp nunâ along the line shown on fig. 2. 
feldspar pegmatites, together with thin folded and boudinaged quartz veins in the basement gneisses, are truncated by the unconformity.

The basement gneisses display shearing along bands parallel to the thrusts. Deep in the pile of thrust slices the gneisses display little shearing and vary from leucocratic to mesocratic lithologies on scales which suggest that their history involved the deformation of nebulitic migmatites before being exposed at the unconformity. In other words, the basement gneisses exposed progressively deeper in the pile are increasingly similar to the autochthonous Archaean gneisses intruded by Kangâmiut dykes exposed so clearly on the north face of Sarfartôq (fig. 3). A crude fracture cleavage low in the pile changes upwards more or less progressively through augen gneisses with a fine grained groundmass rich in (recrystallised) muscovite to rare subhorizontal $5 \mathrm{~cm}$ thick mylonitic bands.

\section{(4) Late basic hypabyssal intrusives}

Amphibolites and foliated amphibolites (hornblende + feldspar \pm garnet) form a sizeable proportion of the rocks at Sarfartûp nunâ. Many rocks of this suite are strongly foliated feldspathic hornblende schists ( \pm garnets). Most display a strong lineation but some of the more massive bodies have suffered partial hydration but little penetrative strain and still display gabbroic textures. In thrust slices 1 and 3 small scale compositional banding is obvious in some localities and in one case (slice 3 ) trough bedding is preserved. The contacts of most of these bodies parallel the bedding in the metasediments and the banding in the metavolcanics and gneisses, but in a few places they transgress the layering at a steep angle. In most such transgressions the sills appear to have stepped up through a planar layered sequence. However, in the west of thrust slice 5 a sill seems to have been injected along the axial plane of an early recumbent fold where it indurated the impure quartzite for $50 \mathrm{~cm}$ or so. Other bodies of this suite have garnetiferous margins; malachite stains some outcrops but no sulphides responsible for such stains were obvious.

The sills of this suite of basic hypabyssal intrusives spread extensively at particular levels in the supracrustal succession and are generally less penetratively deformed than the rocks they intrude. Nowhere were they seen to cross any of the thrusts. Instead, they are truncated by many thrusts and are interpreted as having been intruded into the already deformed and metamorphosed supracrustals before the whole complex was detached, translated and emplaced at Sarfartûp nunâ where it was further deformed and metamorphosed.

\section{Kimberlites}

The only undeformed and unmetamorphosed rocks seen at Sarfartûp nunâ are five minor biotite-rich kimberlite dykes cutting the allochthon (and possible autochthon) on various trends near some late normal faults in the south-west quadrant (fig. 2). About $120 \mathrm{~m}$ south of the lake at $1260 \mathrm{~m}$ a steep E-W trending bifurcating dyke up to $10 \mathrm{~cm}$ wide is rich in carbonates, including rhodonite. 


\section{Structures and metamorphism}

The rocks at Sarfartûp nunâ are interpreted as an accumulation of thrust nappes which have travelled a large distance in a general south or south-south-east direction. After their arrival at or near their present locations, groups of thrust slices developed similar structures but at times and to degrees dependent on their level in the pile. The poles to bedding and lithological contacts in the supracrustal rocks (fig. 5a) define a steep north-north-west to south-south-east girdle. This girdle is $60-100^{\circ}$ wide as a result of at least four separable events in the deformation history. Poles to the axial surfaces of the first two generations of folds lie in groups which together make up a rather similar girdle (fig. $5 \mathrm{~b}$ ). Poles to the third generation of (minor) folds lie in the north-east and western quadrants of figure $5 \mathrm{~b}$. Most of the linear features measured at Sarfartûp nunâ lie within $50^{\circ}$ of a plane striking $100^{\circ}$ and dipping $74^{\circ} \mathrm{S}$ (fig. $5 \mathrm{c}$ ). The only exception to this is a set of axes of necking which fall close to the pole to this plane (fig. 5c). The lineations concentrate in the east-south-east within this

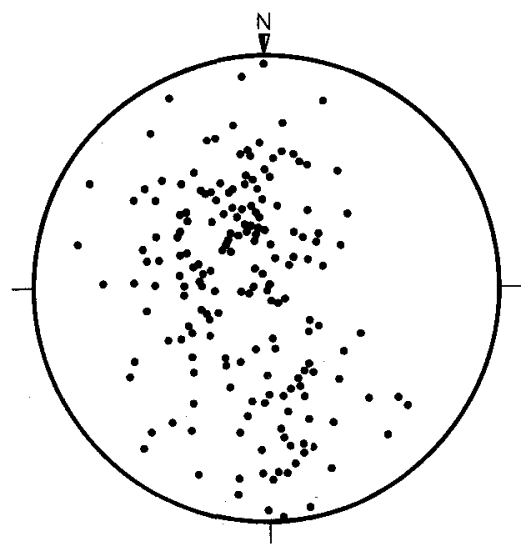

A) POLES TO BEDDING

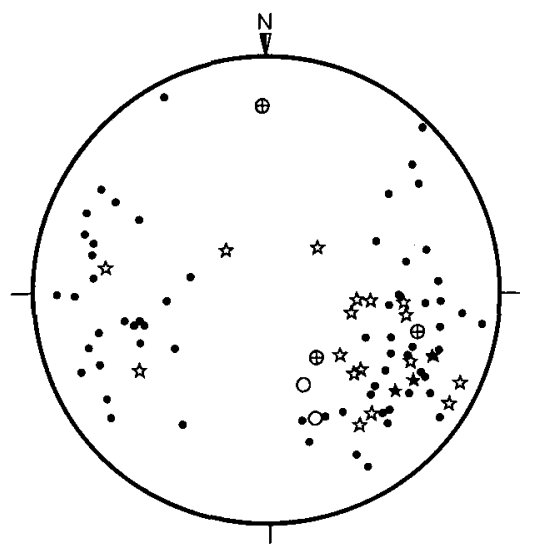

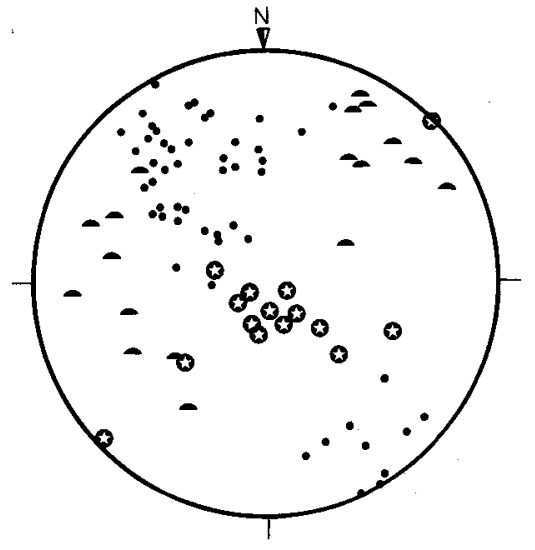

B) POLES to AXIAL PLANES

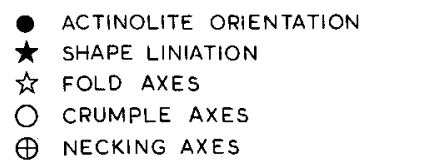

C) LiNEATIONS

Fig. 5. Lower hemisphere equal area stereographic projections of poles to various structural elements at Sarfartûp nunâ. 
partial girdle. The gap in the girdle relates to the $130^{\circ}$ interlimb angle of the depression in the late major east-north-east striking synform affecting the whole of the klippe of supracrustal rocks.

\section{Pre-detachment structures and metamorphism?}

All the components of the second generation of basic igneous rocks predate all the thrusts. However, a (foliated) sill cross-cuts the bedding and layering of several supracrustal units along what could be the axial plane of a major recumbent fold in the west of thrust slice 5 (figs. 2 \& 4 -but see fig. 8). Elsewhere in the klippe the recumbent folds which were the first to have affected the thrusts have an axial plane strain-slip cleavage. This cleavage crenulates an earlier pre-detachment and/or syn-translation foliation in both the sediments and volcanics; furthermore, it developed in pelitic metasediments which already bore biotite (and garnet?) and metavolcanics which were already actinolite-albite schists. Some of the early minor folds have symmetries which suggested that they are older than the large recumbent first folds to affect the thrusts. The extrapolations of the lithological contacts between outcrops shown on fig. 2 are somewhat stylised and some (the anthophyllite schists in particular) might well disguise fold interference patterns involving any such pre-detachment folds.

\section{Thrusts}

At least eight major and two minor thrusts slices are defined by discordant sets of interconnected thrusts on figure 2 . However, further thrust slices are visible in the southern face of Sarfartôq below what is shown as the lowest thrust on figures 2, 3 and 4. It is considered unlikely that such extra lower slices extend outside the southern limit of the klippe shown on figure 2. This is because of a combination of tectonic overstep to the south combined with tectonic offlap to the north within successively higher thrust slices (fig. 4 and later). Nevertheless, some doubt remains as to whether the structurally lowest rocks on figures 2,3 and 4 etc. are truly autochthonous (as shown) or not.

\section{First folds to affect the thrusts}

Once in place, the allochthonous thrust slices at Sarfartûp nunâ developed major folds on axial surfaces which are most easily recognised where they are inclined generally northwards at low angles $\left(20^{\circ}-30^{\circ}\right)$. Such recumbent folds are still obvious in the upper nappes and can be inferred to have had inverted (short) upper limbs from the attitudes of some of the pillows and the compositional banding in the gabbroic sills in the hinges (fig. 4). Minor folds of this generation are discernable amongst the well foliated rocks on a variety of scales. Nearly all the actinolite and hornblende schists have a pronounced mineral orientation lineation (emphasised by quartz in strain shadows around early garnets in the hornblende schists). This lineation, together with shape fabrics in the pillows and agglomerates, is parallel to the first fold axes. Both have been affected by later deformation but seem least disturbed where they plunge gently to the south-east or east-south-east (fig. 5c). Boudinage or, more commonly, necking affects a few of the basic sills and many of the anthophyllite 
schist layers. Although such necking (since refolded) was seen on both north south and east west axes (fig. 5c), nowhere were necks in both directions clearly identified in the same unit. The lineation suggests early constriction and the necking on two axes indicates flattening. These early phases of the deformation in the allochthon will be matched later with similar phases in the early structural history resolved for the gneisses and Kangâmiut dykes of the autochthon nearby by Escher $e$ al. (1975 p. 165).

The translation and arrival of the thrust slices seem to have involved retrogression in both grain size and mineral phases with syntectonic recrystallisation in the lower amphibolite metamorphic facies. New axial planar fabrics are generally rare but in the metapelites a few new biotites (pleochroic dark red-brown to colourless) define a crude foliation oblique to the earlier foliation defined by coarse biotite (pleochroic pale yellow brown to dark brown).

\section{Second folds to affect the lower thrusts}

As the higher thrust slices (4 and 3) arrived disconformably over those already present, the deep slices began to fold about east-north-east trending axial surfaces which dip steeply north-west. These appear to be associated with the main synformal basin in which the supracrustals are now preserved. The axes of these folds are nearly co-axial with the earlier folds and the lineations defined by both the mineral orientation and shape fabrics.

The style of this, the second post-translation deformation, depends on the lithology concerned. Shortening along an axis with a gentle NNW inclination rendered the shape fabric in the previously horizontally flattened pillows and agglomerates prolate. The wavelength and amplitude of the folds varies from perhaps $300 \mathrm{~m}$ in the slabs of basement gneiss, through about $5 \mathrm{~m}$ in the calc-silicate and carbonate layers, to a fine crenulation or strain-slip cleavage in the schistose and phyllitic effusives and metasediments. The calc-silicate and hornblende schists tend to display concentric fold styles while the schists and phyllites developed conjugate kinks or chevron folds - which everywhere fold the early actinolite and hornblende orientation lineations. The degree of development of these folds noticeably decreases upwards in the structural section and the upper thrusts (e.g. 2) either truncate them or acted as an upper décollement surface (fig. 6).

The folds on steep axial surfaces are the second or third to develop in some of the gneisses and most of the deeper supracrustals but are often the first to affect the late suite of basic sills where these escaped the earlier recumbent folding. An amphibolite just east of the lake at $1160 \mathrm{~m}$ can be identified as having been discordant to both the bedding and an earlier foliation in the schists before it developed a foliation itself during the folding on steep axial planes (fig. 7).

While the early recumbent folds in the deeper rocks were refolding about steep axial planes it seems likely that the shallower rocks (e.g. in thrust slice 1 and possibly 2) were still folding on recumbent axial planes. Some recrystallisation and mineral growth probably accompanied the deep folding associated with the arrival of the upper thrust slices but this phase appears to have been largely one in which earlier minerals were folded. About $70 \mathrm{~m}$ south of the summit cairn a vein (strike $053^{\circ}$ dip $78^{\circ} \mathrm{NW}$ ) of anthophyllite asbestos developed along the axial surface of one of the few folds of this generation (amplitude about 1 $\mathrm{m})$ to develop so high in the pile. The fibres in this vein are up to $50 \mathrm{~cm}$ long and oblique to the vein and record a trajectory of extension now (surprisingly) plunging $23^{\circ}$ towards $126^{\circ}$. 

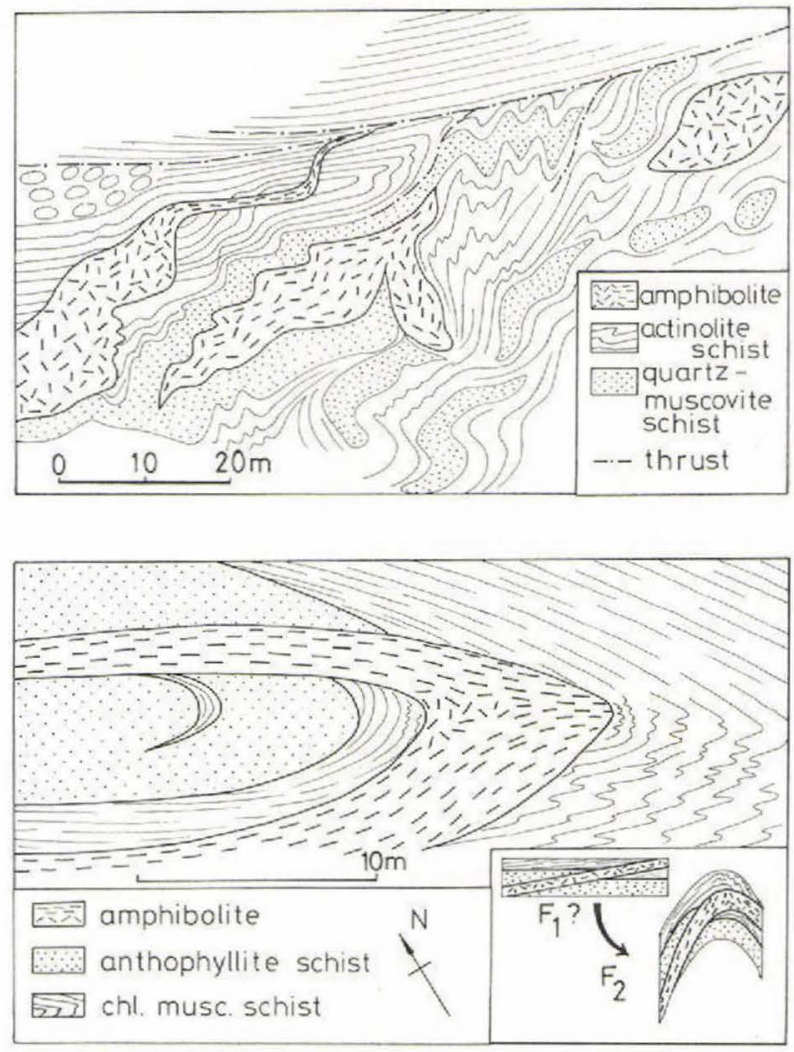

Fig. 6. Isotropic or foliated garnet amphibolites cross predetachment folds in the actinolite and calcareous muscovite schists WNW of the lake at $1260 \mathrm{~m}$. The syn-translation foliation in the amphibolites and the boudins in the calc-silicate beds are folded about the second post-arrival folds on steep axial planes. It is not clear whether these folds are truncated by the thrust or die out to a décollement along it but they are only represented by fine crenulations in the overlying thrust slices $(1 \& 2)$.

Fig. 7. A feldspar amphibolite, discordant with previously foliated metasediments, folded and foliated during the second post-arrival folding. Location east of lake at $1160 \mathrm{~m}$. Inset shows reconstructed strain history,

Some acicular anthophyllite in some of the anthophyllite schists show syn-kinematic alignment but most are post-kinematic garbenschiefer and presumably post-date the folds on steep axial planes. Post-kinematic porphyroblasts developed in other rocks at about this stage: kyanite in the pelites, more garnet in some of the hornblende schists and rhombs of calcite (at the expense of anthophyllite) in some of the chlorite-rich calc-silicate schists. However, generally, the only metamorphism to follow the two major post-translation deformations was an annealing in the lower amphibolite facies. Thus quartz and garnet recrystallised to more stable mutual boundaries and formerly bent anthophyllite, actinolite, micas and chlorite polygonised. Veins of chlorite up to $15 \mathrm{~cm}$ thick in many of the thrusts either developed at this stage or were recrystallised so that they now consist of large flakes of chlorite perpendicular to the thrusts.

\section{Final minor folds and the faults}

In the highest thrust slices ( 2 and 1 ) the second folds on steep axial surfaces are characteristically only minor crumples with a wavelength of $<2 \mathrm{~cm}$. These appear synchronous in some places and refolded in others by one or two conjugate sets of minor crenulations which 
trend respectively NNE and dip more than $70^{\circ} \mathrm{WNW}$ and trend NE and dip almost as steeply to the SE. The late minor crenulations result in extremely complex patterns of folds in the phyllites and are the only structures which visibly affect the anthophyllite rosettes.

Various late faults interrupt all the earlier structures. The most obvious has a N-S strike and affects thrust slices $8 \& 9$ at the west end of the klippe and may be contemporaneous with the kimberlites thereabouts.

\section{Interpretation}

A crude palinspastic reconstruction of the thrust slices shown in figure 4 is illustrated in figure 8 . In the absence of quantitative strain data all the distortions so obvious in figure 4 are removed only qualitatively in figure 8 . The doubt concerning the pre-detachment folding (rather than the syn-translation foliation) is emphasised by the two interpretations of thrust slice 5 shown in figure 8.

The general similarity of the successions preserved in each slice is immediately obvious. The thrust slices can be seen to have come from an area of acid gneisses covered unconformably by a thin sequence of subaqueous volcanics and impure carbonates. These rocks accumulated together with clastic sediments which were derived from a quartz-rich source. There is sufficient relief on the unconformity preserved in thrust slice 8 to suggest that it was the result of subaerial erosion. According to Escher, Sørensen \& Zeck (1976) this is the first report of the pre-Nagssugtoqidian basement unconformity not obliterated by deformation. The amygdaloidal nature of many of the sub-aqueous volcanics, the micaceous sandstones and the impure carbonates all suggest that the supracrustals accumulated in shallow marine conditions. Any overstep or offlap could probably be recognised by further work but any palaeoslope during the depositional phase has been missed by the present study.

Nowhere in the allochthonous units are there thicknesses exceeding $300 \mathrm{~m}$ of the basement gneisses or $200 \mathrm{~m}$ of the supracrustals (after subtracting the thicknesses of later basic sills). These thicknesses are limited upwards by thrusts as well as by erosion (fig. 9). The preor syn-detachment lower amphibolite metamorphism suggests that the supracrustals were originally thicker, and the late kyanite implies they were buried deeply after arrival. However, while none of the late suite of basic intrusions are noticeably vesicular, the supracrustal sequence must have been sufficiently shallow for the sills to have lifted their overburden when they were indtruded.

Examination of figures 8 and 9 makes clear that these sills spread more or less extensively along at least three levels in the basement gneisses, at several levels within the volcanics but, in particular, along the major unconformity between the cover and its basement where sediments lay along it. It is not clear whether this sill generally avoided stretches of the unconformity where volcanics lay directly on the gneisses because the magma was incapable of splitting such a contact or whether the contact was too steep. Traced from south to north this suite of intrusion involves five major $(>70 \mathrm{~m})$ transgressions or step-ups through the succession and three minor $(<20 \mathrm{~m})$ step-downs (figs. 2 and 9 ). As basic magma is likely to step-up towards shallower levels (cf. ramps on listric thrusts) this relationship suggests that the regional dip was generally to the south when the sills were introduced before the detachment occurred along the thrusts (fig. 10).

Detachment along one or more sole thrusts developed well within the gneissose basement. 


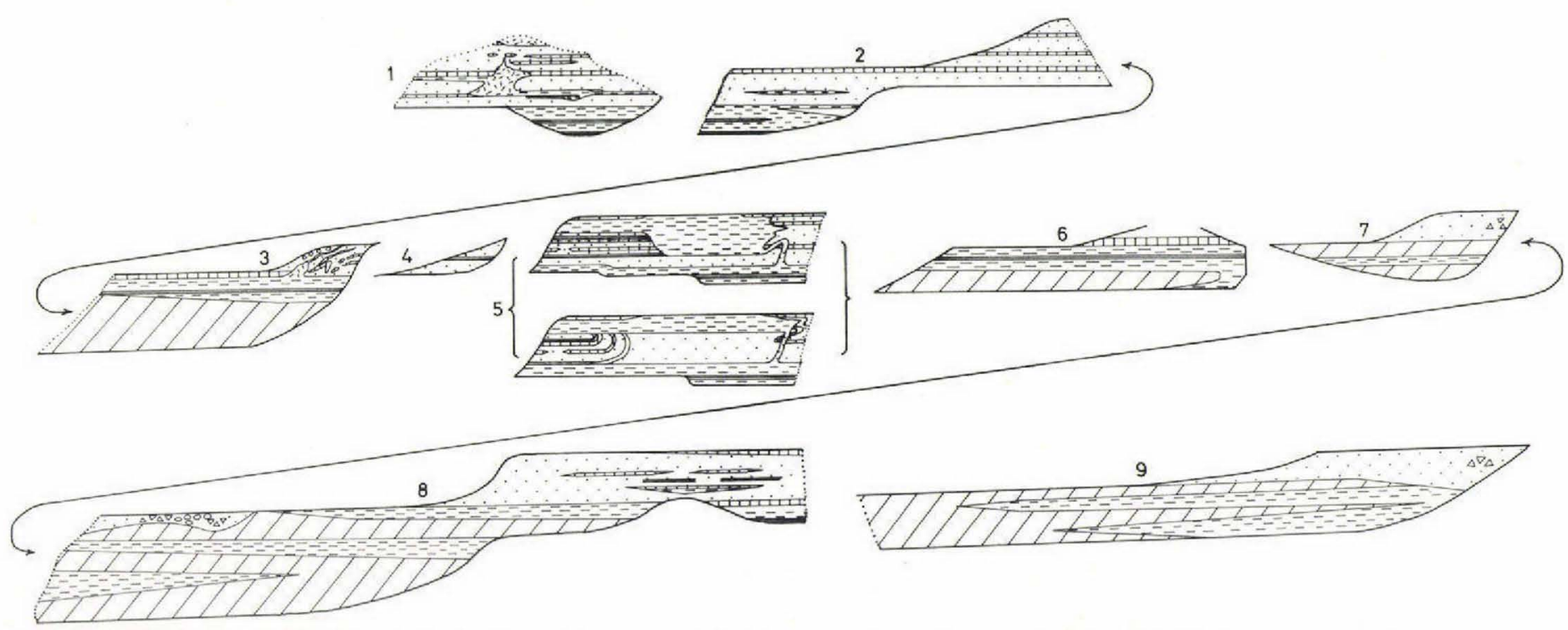

Fig. 8. A palinspastic reconstruction of the thrust slices shown on fig. 4. Symbols as for fig. 2. Two alternative reconstructions are shown for thrust slice number 5 . 


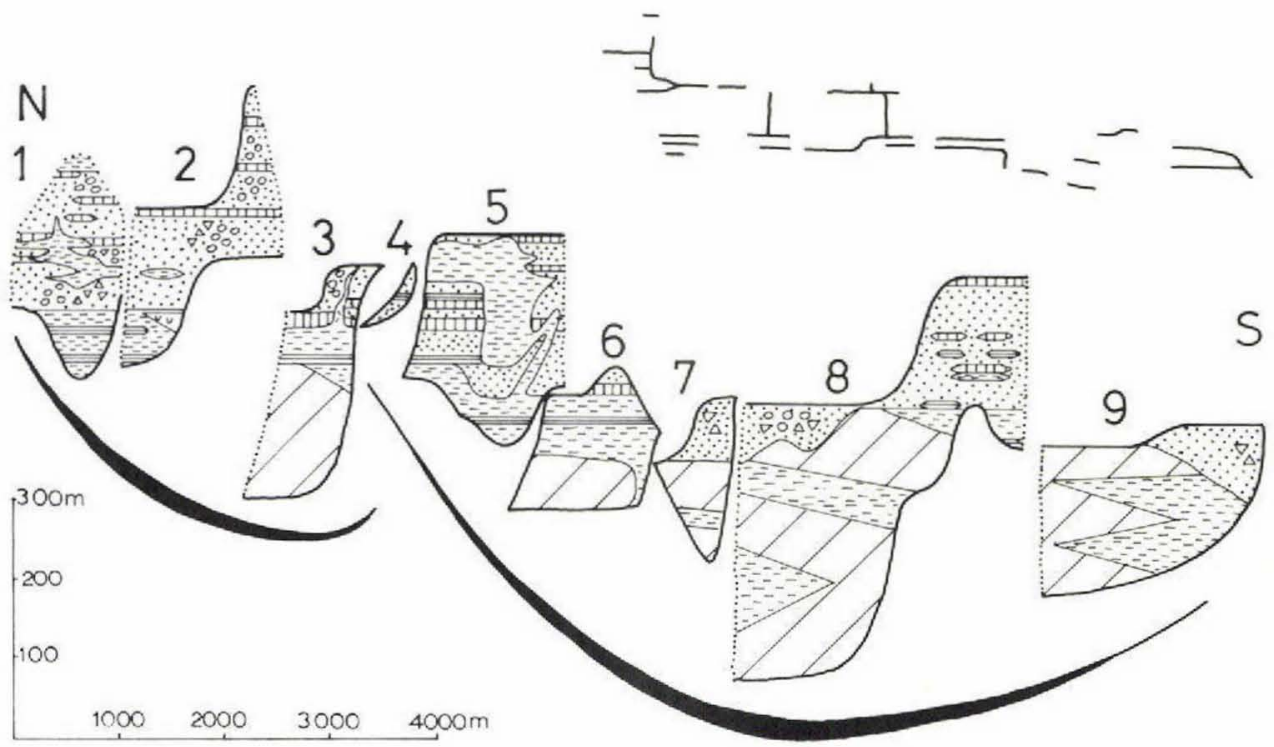

Fig. 9. A palinspastic reconstruction of the thrust slices with an abbreviated horizontal scale to emphasise the stratigraphic similarities from slice to slice. The heavy brackets indicate the two groups of thrust slices referred to in the text. Line boundaries represent thrusts and dotted boundaries represent present erosion surfaces. The late suite of metabasic intrusives has been removed from the lower diagram and is shown in outline above on a smaller scale.

Thrust flats (or treads) developed within the leucocratic gneisses (rather than the foliated amphibolites) and at various levels within the metavolcanics but in particular along the major basic sill injected along the unconformity between the basement and the supracrustal cover. Ten or so major thrust ramps (or risers) step-up the succession in a general southerly or SSE direction but two minor thrusts step-down the sequence to the south or SW (figs. 2 and 9). It is generally assumed that thrusts cut up section in the direction of transport (Dahlstrom, 1970; Elliott, 1976a). Furthermore thrusts always move in the direction of the surface slope even if this means moving up the sole thrust (Elliott, 1976a). The thrust slices at Sarfartûp nunâ therefore travelled generally north to south or towards the SSE and the palaeosurface at least was inclined down to the S or SSE as they moved.

The imbricate thrust slices fall into two groups (indicated by thick black brackets in fig. 9). In each of these groups the lower nappes incorporate basement gneiss while the upper slices do not. Imbricate slices probably developed successively deeper beneath the higher slices in each group before coming together with marked tectonic disconformities in the accumulation zone (fig. 10b and c). Either, contrary to current opinion, the two separate sole thrusts developed beneath each group of thrusts dipped down in the direction of movement or the unconformity between the cover and basement dipped to the north and the sole thrusts stepped up to the south (fig. 10b). 


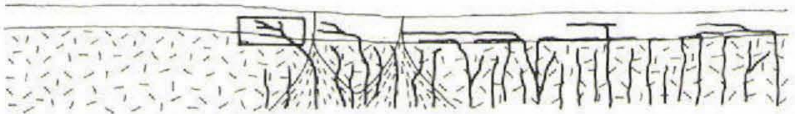

a

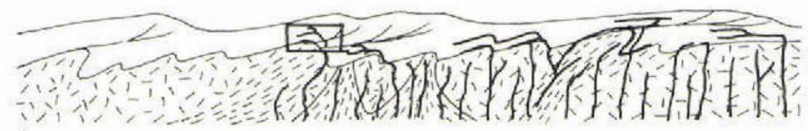

b

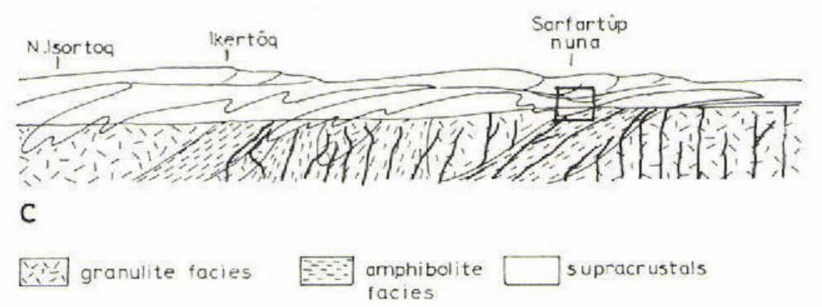

Fig. 10. A schematic reconstruction of a N-S section through the Nagssugtoqidian mobile belt. (a) after the Kangâmiut dykes and sills were introduced following the Nag. 1. transcurrent shears, (b) further Kangâmiut dykes are assumed to have been introduced during the early stages of ductile overthrusting and (c) the current situation with a deformed pre-Nagssugtoqidian cover sketched in above the present level of erosion. In all three diagrams the suggested location of the rocks now at Sarfartûp nunâ is indicated by a box.

\section{Discussion}

Despite their small area the rocks at Sarfartûp nunâ have implications for both regional Nagssugtoqidian geology and for detachment tectonics in general.

\section{Regional correlation and derivation}

There must inevitably be some doubt as to the derivation and timing of allochthonous rocks in such an isolated klippe as that at Sarfartûp nunâ. The most doubt concerns the derivation for each of the units. However, many of the structures at Sarfartûp nunâ have what are considered abvious correlatives in the underlying autochthon to the north.

On the basis of their studies of the deep autochthon along the southernmost margin of pronounced Nagssugtoqidian ductile overthrusting Escher et al. (1975), p. 172) predicted that, "if a supracrustal cover existed, as seems probable, we would anticipate it to be characterised by south-easterly directed nappes, formed by thrusting of basement wedges, or by gravity". This prediction is confirmed by the rocks at Sarfartûp nunâ if the correlation suggested below (and summarised on table 1) is acceptable. The key to this correlation lies in equating the early igneous rocks at Sarfartûp nunâ with the early east-west dykes in the autochthon and the later suite of basic sills in the supracrustals with the main Kangâmiut dyke swarm in the autochthon. However, no geochemical comparisons of these rocks have been attempted. 
Table 1. Correlation of rocks at Sarfartûp nunâ with the main events in the Nagssugtoqidian

\begin{tabular}{ll}
\hline $\begin{array}{l}\text { autochthon } \\
\text { (after Escher et al., 1975) }\end{array}$ & $\begin{array}{l}\text { allochthon at } \\
\text { Sarfartup nuna }\end{array}$ \\
\hline
\end{tabular}

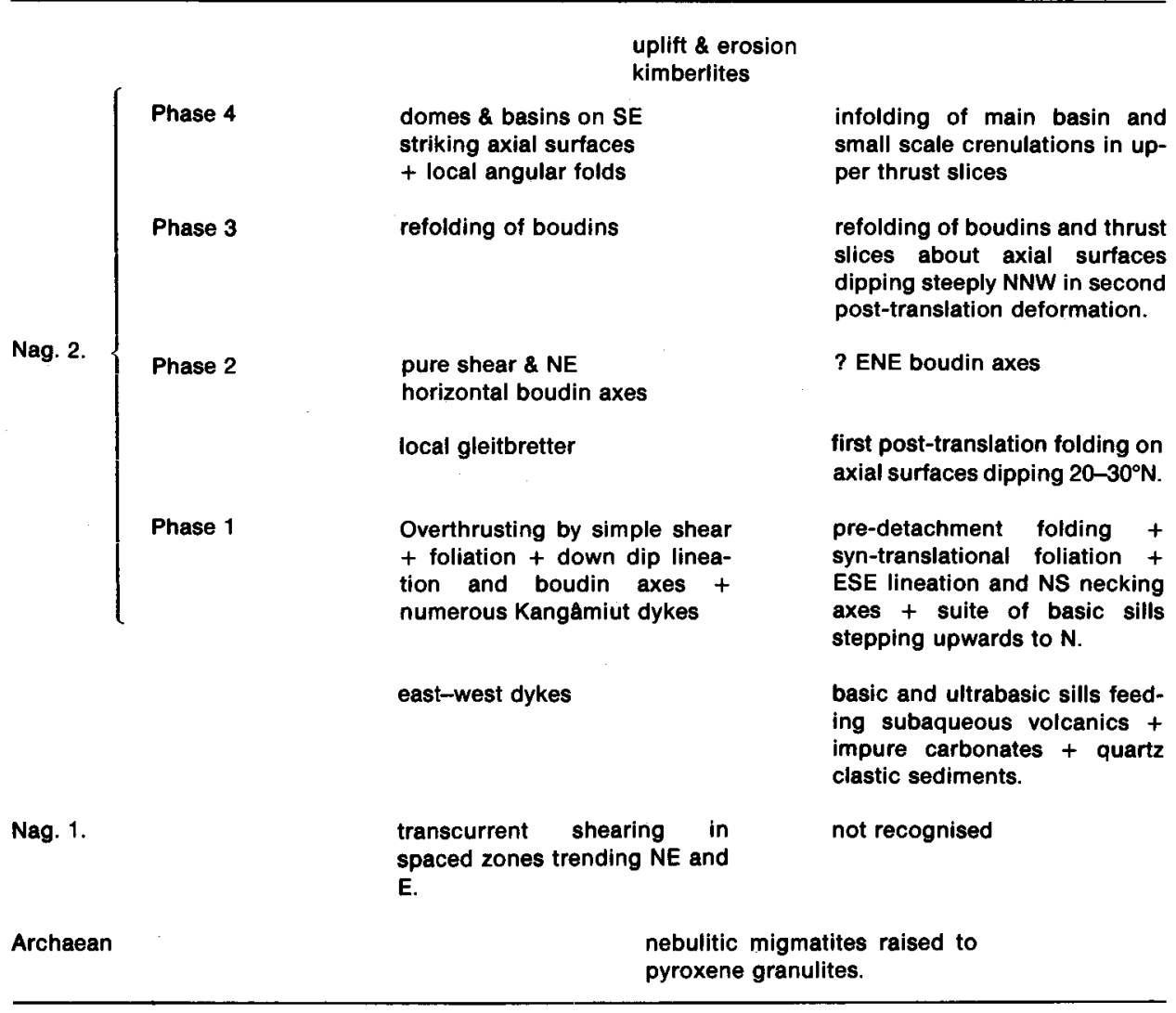

The first major deformation of the Nagssugtoqidian mobile belt led to Archaean granulitic facies gneisses being retrogressed to amphibolite facies in several north-east and east trending zones of transcurrent shear (Bak et al., 1975). Such early localised transcurrent shearing was followed by a sparse set of east-west dykes. In table 1 these are assumed to have supplied the high level hypabyssal intrusions at Sarfartûp nunâ. These in turn fed the sub-aqueous volcanics which would have looked like a (?small) ocean basin from above as they covered the sialic basement. The early east-west dykes were followed in the autochthon by a dense swarm of Kangâmiut dykes which preceded the second major Nagssugtoqidian deformation, a ductile overthrusting from the north-north-west (Escher et al., 1975; Watterson, 1974). The suite of basic sills at Sarfartûp nunâ is interpreted as a high level equivalent of the main swarm of Kangâmiut dykes.

Escher et al. (1975) divided the second major Nagssugtoqidian deformation along the southern margin of the mobile belt into four phases each of which can be equated with shallow level events preserved at Sarfartûp nunâ. 
A strong foliation and down dip lineation and set of necking axes developed in the autochthon during an early phase of overthrusting by simple shear (Escher et al., 1975). This early phase developed into a pure shear flattening during which further (horizontal) axes of boundinage developed. Such structures at depth were accompanied at shallow levels by an early metamorphism in low amphibolite facies, a possible pre-detachment folding, and detachment and translation in hydrous conditions with the development of a strong lineation and boudinage on two axes. Early gleitbretter in the autochthon are probably matched by the first recumbent folds to affect the thrusts at Sarfartûp nunâ. The lineation and fold axes at Sarfartûp nunâ concentrate in the east or east-south-east rather than down dip (fig. $5 \mathrm{c}$ ). They are therefore oblique to the SSE direction of thrusting inferred from their imbrication. This situation may be similar to the attitude of fold and fabric axes in glaciers which parallel the flow direction throughout most of their mass but are strongly oblique to the flow direction along the centre line and in the snout.

In what Escher et al. (1975) called the third phase in the autochthon the early boudins were refolded at some localities. The boudins in the rocks at Sarfartûp nunâ were also folded. However, at Sarfartûp nunâ they were folded during the second folding to affect the lower thrusts and this occurred about axial surfaces dipping steeply north-north-west. The fourth phase recognised in the autochthon resulted in large scale open domes and basins on south-east striking axial planes which are associated with small scale angular folds at some localities. These structures correlate with the infolding of the entire klippe at Sarfartup nunâ together with the late minor conjugate crenulations developed in its upper slices.

Sarfartûp nunâ is not unique in preserving supracrustals of low metamorphic grade within the Nagssugtoqidian mobile belt. Another synform, of anthophyllite schists, phyllites, marbles and pillow lavas has been reported $85 \mathrm{~km}$ north-east of Sarfartûp nunâ (Escher $e$ t al., 1970). Little is known of these rocks but they occupy a similar tectonic position to Sarfartûp nunâ for they also lie within $15 \mathrm{~km}$ of the south-east edge of the Nagssugtoqidian mobile belt (fig. 1).

The palinspastic reconstruction (figs. 8 and 9) indicates that wherever the allochthon at Sarfartûp nunâ came from was originally at least $11 \mathrm{~km}$ in north-south section and, though it may now be shortened from north to south, its original supracrustal cover is missing. The area of derivation must also contain both the early east-west dykes and the Kangâmiut dykes and these are reported to die out north of Ikertôq (Escher et al., 1975). This places a northerly limit of some 50 or $60 \mathrm{~km}$ to the likely area of derivation. The area of derivation is also expected to show ductile overthrusting developed during the second major Nagssugtoqidian deformation and such overthrusting is apparently limited to just two zones (Watterson, 1978). One of these borders the south-east margin of the Nagssugtoqidian mobile belt and lies beneath Sarfartûp nunâ (fig. 1). This zone is about $15 \mathrm{~km}$ wide, dips about $20^{\circ}$ to the north-north-west and is not known to involve autochthonous supracrustal rocks. The other is about $10 \mathrm{~km}$ wide, dips $50^{\circ}$ north-north-west, meets the coast north of Ikertôq (fig. 1), and involves calc-silicate, graphitic and clastic metasediments with both concordant and discordant amphibolites. Grocott (1977) has interpreted the discordant amphibolites as deformed Kangâmiut dykes (see also Korstgård, this volume).

Three other areas of pre-Nagssugtoqidian supracrustals have been reported in the autochthon north of Sarfartûp nunâ. Two of these are best known around Agto (Escher, Sørensen \& Zeck, 1976). One contains hornblende schists, ultrabasic lenses and metasediments but contains thick pure marbles and widespread graphite and therefore differs from 
the supracrustals at Sarfartûp nunâ. The other consists of paragneisses, marbles and calc-silicates with foliated amphibolites; however, no metavolcanics have been reported from either. A third group, near Ugssuit (Escher et al., 1976) consists of basic actinolite schists with quartzites and amphibolites, a description which is comparable with that of the rocks at Sarfartûp nunâ.

If the structurally lowest quartzites at Sarfartûp nunâ are autochthonous (as shown at the west end of fig. 2) then the thrust slices of the klippe have not moved far and the area of derivation extends about $11 \mathrm{~km}$ northwards of their present location. However, if, as suspected, further thrusts have yet to be identified below the sole thrust shown at the western end of Sarfartûp nunâ on figure 2 then the area of derivation is more likely to be $50-60 \mathrm{~km}$ to the north.

The rocks at Sarfartûp nunâ appear to be so allochthonous on the zone of overthrusting on which they are now preserved that it is considered more likely that they were derived from the more northerly of the two known zones of overthrusting, from a part in which the supracrustals are missing. Although Korstgård (pers. comm.) has extended eastwards the supracrustals shown by Grocott to exist on the coast in the Ikertôq shear zone, it is anticipated that the supracrustals will be missing from this zone inland of Ikertôq itself. Figure 10 is based on this interpretation.

After considering the possibility that the dyke swarms of the North Atlantic Proterozoic craton defined the margins of thin but extensive lithospheric plates Escher et al. (1976) concluded that they were intracontinental or intraplate phenomena (see Windley, 1977, p. 69). Watterson (1978) has gone further and interpreted the Proterozoic dyke swarms and the Nagssugtoqidian reworking in Greenland as part of a wholesale pattern of Proterozoic shearing throughout the North Atlantic continental lithosphere. The shearing is interpreted as having been induced by continental collision along a suture "unrecognised in south Greenland or lying to the south of Cape Farewell" (Watterson, 1978). In this inspiring picture, the large comparatively undisturbed block of Archaean rocks of southern Greenland represents a dead triangular region in the indented plate in front of a relatively northward moving rigid Ketilidian plate simultating an indenting die. Sarfartûp nunâ lies comparatively close to the apex of the triangle limited by the Nagssugtoqidian zones of remobilisation and fits the picture neatly. The movement of the thrust slices south or south-south-east to Sarfartûp nunâ demonstrates that the surface slope at least was inclined in that direction. This is in accord with the crustal thickening around the dead triangle inferred by Watterson (1978) from the boundaries of the rocks of granulite metamorphic facies.

\section{Comparisons}

The allochthonous supracrustal rocks at Sarfartûp nunâ bear comparison with some obducted ophiolites in younger rocks and some greenstone belts in older rocks; indeed, they might usefully be considered as Proterozoic intermediates of both.

Had the metasediments and subaqueous volcanics associated with basic and ultrabasic hypabyssal intrusions of Sarfartûp nunâ been translated without the acid basement gneisses beneath them, the result would have looked remarkably like the present ocean floor and many of those obducted ophiolites without sheeted dyke complexes. However, the sole 
thrusts developed well within a basement which is definitely continental in character. The equivalent of the sheeted dyke complex beneath those obducted ophiolites which have them is the Kangâmiut dyke swarm which in its exposed $140 \mathrm{~km}$ width only represents a crustal extension of 2-3\% (Escher et al., 1975). Nonetheless it may be useful to realise that at least part of the Kangâmiut dyke swarm would have been overlain by what would have looked like a small ocean basin at the time.

Sarfartûp nunâ also shares similarities with those Archaean greenstone belts in which successions of basic volcanics and metasediments of low metamorphic grade were thickened by thrust and fold repetition before subsequently being infolded into a basement of acid gneiss (see Windley, 1977, p. 23).

The supracrustal rocks infolded with an acid basement at Isua form one of the oldest greenstone belts in the world. They also form the Archaean greenstone belt closest to Sarfartûp nunâ being $180 \mathrm{~km}$ to the SSE (Bridgwater et al., 1976). In general the lithologies at both localities are very similar and some of the clasts in the conglomerates at Isua were derived from an acid gneiss basement with high relief. Only the metamorphosed banded ironstones, conglomerates and acid volcanics at Isua are not matched by similar lithologies at Sarfartûp nunâ. The structural histories of these two areas are also similar to the extent that both suffered early deformations involving intense shearing more or less parallel to the lithological contacts in the supracrustals and the banding in the gneisses. The second major deformation recognised at both localities also involved folding about axes nearly co-axial with the lineation developed in the earlier foliation. An intriguing obliquity of the internal lithological contacts with the bounding margins of the Isua belt (James, 1976) might be equivalent to a similar relationship at Sarfartûp nunâ where it can be seen to be due to imbricate thrusting.

Despite these similarities however, the supracrustal rocks at Isua are inferred to already have been infolded into a rim syncline around a basement gneiss dome before the first obvious deformation affected them (James, 1976). Furthermore, the second obvious event at Isua was accompanied by the intrusion of a set of tangential basic dykes in its early stages and a radial swarm in its later stages.

Unlike most greenstone belts, that at Isua has not suffered what James (1976) called major post-deformational plutonic activity but what might often be merely a remobilisation of the surrounding basement gneisses. The Isua greenstone belt could therefore be considered as having survived in a less mature tectonic state than most. The considerably younger Proterozoic greenstones at Sarfartûp nunâ could preserve an even earlier stage in the development sequence suffered by most Archaean greenstone belts. This is because its infolding into the basement gneiss was insufficient to disguise the autochthonous imbricate thrust slices of which it consists. Had the Sarfartûp nunâ region ever been warmed more than it was the heavy greenstones would presumably have sunk in the surrounding gneisses to produce an outcrop pattern far more like the greenstone belts so typical of many parts of the surviving Archaean crust.

\section{Displacement tectonics}

The flats and ramps of the listric thrusts at Sarfartûp nunâ have similar length ratios to thrust slices in many younger rocks. However, the nappes at Sarfartûp nunâ are generally 
smaller and appear to have many more internal structures than are reported from equivalent areas of younger rocks. They deformed penetratively throughout their preserved thicknesses whereas, in the Canadian Rocky Mountains for example, the much larger nappes suffered penetrative deformation only in their lower halves (Elliott, 1976b, p. 310). Unlike such younger examples the sole thrusts at Sarfartûp nunâ did not form a décollement over an undeformed basement. Instead they developed deep within the basement which was itself overthrusting more or less penetratively. Similarly, the supracrustals at Sarfartûp nunâ did not come to rest on a stable foreland but are preserved approximately $15 \mathrm{~km}$ short of the boundary of marked Nagssugtoqidian strain, still well within the mobile belt.

All the above differences between the thrust nappes at Sarfartûp nunâ and those in younger rocks imply an extra mobility in the Proterozoic examples. Although this may be a function of level of exposure, a comparison of the sections through the main ranges of the Canadian Rocky Mountains and Sarfartûp nunâ suggests that this extra mobility is real. A steeper thermal gradient in the Nagssugtoqidian crust could account for this.

Elliott (1976a) took the sole thrust to typical Mesozoic thrust sheets in the Canadian Rocky Mountains to be $10 \mathrm{~km}$ deep and calculated an average basal shear stress to be of the order of 50 bars in that area at that time. The maximum thickness of the thrust slices preserved at Sarfartûp nunâ is only about half a kilometre and the approach used by Elliott is only strictly applicable to thrusts deeper than $5 \mathrm{~km}$. Nonetheless, using Elliott's approach, such a thickness implies basal shear stresses of only about 1.3-2.6 bars depending on the surface slope used for the calculation. Even if a considerable vertical flattening is taken into account the basal shear stresses calculated in this way do not approach anything like the values calculated for sole thrusts in the Canadian Rocky Mountains. Indeed, the basal shear stresses for glaciers are thought to be about 1-1.5 bars. These deform with an effective viscosity of around $10^{14}$ poises $\left(10^{10} \mathrm{~m}^{2} \mathrm{~s}^{-1}\right)$ and usually flow at rates of tens or even hundreds of metres per year $=3 \cdot 10^{-7}$ to $3 \cdot 10^{-6} \mathrm{~m} \mathrm{~s}^{-1}$ (Shumskii, $1964 \mathrm{pp} .312-315$ ). These rates of movement are far faster than those of the nappes in the Rocky Mountains which are calculated to have moved at a rate of about $6.10^{-11} \mathrm{~m} \mathrm{~s}^{-1}$ (Elliott, 1976a). Such analogies suggest that the Proterozoic thrust slices at Sarfartûp nunâ were not only much smaller than younger examples but that they moved almost as rapidly as modern glaciers.

Acknowledgements. This work was undertaken as part of the Liverpool University Precambrian Boundary programme directed by Dr. J. Watterson and supported by N.E.R.C. grant GR3/1785 (see Diggens \& Talbot, 1974). Travel funding from the Carnegie Trust for the Universities of Scotland and the University of Dundee are greatly appreciated.

\section{References}

Bak, J., Korstgård, J. \& Sørensen, K. 1975: A major shear zone within the Nagssugtoqidian of West Greeland. Tectonophysics 27, 191-209.

Bridgwater, D., Keto, L., McGregor, V. R. \& Myers, J. S. 1976: Archaean gneiss complex of Greenland. In Escher, A. \& Watt, W. S. (edit.) Geology of Greenland, 19-75. Copenhagen: Geol. Surv. Greenland.

Dahlstrom, C. D. A. 1970: Structural geology in the eastern margin of the Canadian Rocky Mountains. Bull. Can. Petrol. Geol. 18, 332-406. 
Diggens, J. \& Talbot, C. J. 1974: Nagssugtoqidian supracrustal metavolcanic rocks of Sarfartûp nunâ, Søndre Strømfjord, central West Greenland. Rapp. Grønlands geol. Unders. 65, 37-39.

Elliott, D. 1976a: The motion of thrust sheets. J. geophys. Res. 81, 949-963.

Elliott, D. 1976b: The energy balance and deformation mechanisms of thrust sheets. Phil. Trans. $R$. Soc. Lond. A, 283, 289-312.

Escher, A., Escher, J. C. \& Watterson, J. 1970: The Nagssugtoqidian boundary and the deformation of the Kangàmiut dyke swarm in the Søndre Strømfjord area. Rapp. Grønlands geol. Unders. 28, 21-23.

Escher, A., Escher, J. C. \& Watterson, J. 1975: The reorientation of the Kangâmiut dike swarm, West Greenland. Can. J. Earth Sci. 12, 158-173.

Escher, A., Jack S. \& Watterson, J. 1976: Tectonics of the North Atlantic Proterozoic dyke swarm. Phil. Trans. R. Soc. Lond. A, 280, 529-539.

Escher, A., Sørensen, K. \& Zeck, H. P. 1976: Nagssugtoqidian mobile belt in West Greenland. In Escher, A. \& Watt, W. S. (edit.) Geology of Greenland, 77-95. Copenhagen: Geol. Surv. Greenland.

Escher, A. \& Watt, W. S. (edit.) 1976: Geology of Greenland. Copenhagen: Geol. Survey Greenland, $603 \mathrm{pp}$.

Grocott, J. 1977: The northern boundary of the Ikertôp shear belt, West Greenland. Unpubl. Ph.D. thesis, Liverpool Univ. $179 \mathrm{pp}$.

James, P. R. 1976: Deformation of the Isua block, West Greenland: a remnant of the earliest stable continental crust. Can. J. Earth Sci. 13, 816-823.

Korstgård, J. A. 1979: Metamorphism of the Kangâmiut dykes and the metamorphic and structural evolution of the southern Nagssugtoqidian boundary in the Itivdleq-Ikertôq region, West Greenland. Rapp. Gronlands geol. Unders. 89 (this volume).

Shumskii, D. A. 1964: Principles of structural glaciology. New York: Dover Publications, 427 pp.

Watterson, J. 1978: Proterozoic intraplate deformation in the light of south-east Asian neotectonics. Nature, 273, 636-640.

Windley, B. F. 1977: The evolving continents. London: John Wiley \& Sons, 385 pp.

Department of Geology,

Dundee University,

Scotland DD1 4HN. 